African Journal of Cellular Pathology 3: 9-15 (2014)

The Official Journal of the Society for Cellular Pathology Scientists of Nigeria

www.ajcpath.com

\title{
THE EFFECT OF ASCORBIC ACID ON MERCURY-INDUCED CHANGES ON THE HISTOMORPHOLOGY OF THE CEREBELLUM OF ADULT WISTAR RATS
}

\author{
Ibegbu AO, Animoku AA, Ayuba M, Brosu D, Adamu SA, Akpulu P, Hamman WO, Umana \\ UE, Musa SA.
}
Department of Human Anatomy, Faculty of Medicine, Ahmadu Bello University Zaria Kaduna State-Nigeria

Corresponding Author: Ibegbu AO

Email: aoibegbu@yahoo.com

\begin{abstract}
Aim: The present study was aimed at evaluating the effect of ascorbic acid on mercury-induced changes on the cerebellar cortex of adult Wistar rats.

Methods: Thirty adult Wistar rats of average weight of $200 \mathrm{~g}$ were randomly divided into 6 groups of 5 rats each. The animals in Group 1 (control) were administered with distilled water, Groups 2 and 3 were administered with $52 \mathrm{mg} / \mathrm{kg}$ and $26.25 \mathrm{mg} / \mathrm{kg}$ body weight of $\mathrm{HgCl}_{2}$ respectively while Groups 4 and 5 were administered with $52 \mathrm{mg} / \mathrm{kg}$ of $\mathrm{HgCl}_{2}$ and $5 \mathrm{mg} / \mathrm{kg}$ of ascorbic acid and $26.25 \mathrm{gm} / \mathrm{kg}$ of $\mathrm{HgCl}_{2}$ and $5 \mathrm{mg} / \mathrm{kg}$ of ascorbic acid respectively, while Group 6 was administered with $5 \mathrm{mg} / \mathrm{kg}$ of ascorbic acid. The administration was through the oral route, daily for 3 weeks and the animals were humanely sacrificed. Thereafter, blood and tissue samples were harvested for analysis.

Results: The result of the biochemical parameters showed a significant increase $(\mathrm{P}<0.05)$ in the mean SOD and LPO values after the administration of mercuric chloride and ascorbic acid. Histological observation of the cerebellar cortex showed normal histo-morphology in Groups 1 and 6 while, the cerebellum in Groups 2, 3, 4 and 5 showed some degenerative, necrotic and cellular changes.

Conclusion: Ascorbic acid administration has shown to ameliorate the induced degenerative changes in the cerebellum caused by mercuric chloride toxicity in Wistar rats.
\end{abstract}

Key words: Mercuric chloride, Cerebellar cortex, Ascorbic acid, Wistar rats

\section{INTRODUCTION}

Mercury occurs in the environment as a result of natural processes such as degassing from earth crust, emissions from volcanoes, evaporation from water bodies and anthropogenic processes from coal-fires, power stations, residential heating systems and waste incinerators (Cox, 1997; Burger and Gochfeld, 2011). Mercury can also occur as a result of mining of mercury, gold, copper, zinc, lead and silver (ATSDAR, 1999). There is a growing appreciation of the effects that exposure to heavy metals may cause in the body and in particular, the brain and the nervous system. This is because some of these metals can cross the blood brain barrier and accumulate in the brain and cause damages (Langford and Ferner, 1999; Valko et al., 2005).
Animals and humans interact with their environment on a daily basis and as such are exposed to a broad spectrum of chemicals and heavy metals present in the environment through food, air and water (Burger et al., 2011). The ancient Greek used mercury in ointments while the ancient Egyptians and Romans used it in cosmetics but in China, mercury was thought to prolong life, heal fractures and maintain general good health (Clarkson, 1989; Brian. and Fred, 1995). There are many reported cases of mercury food poisoning in Sweden, Mexico, USA and the Minamata Bay incidence that led to the poisoning of over 800 people. Toxicity of mercury can result from vapor inhalation, ingestion or absorption through the skin. Nervous, digestive and renal systems are most 
commonly affected in mercury exposure while children and pregnant women are most vulnerable to mercury exposure (De Bont et al., 1986; European Commission, 2005). Fishes, mostly tilapia, from Lagos Lagoon of Nigeria are characterized with relatively high level of mercury concentration and this can be attributed to industrial effluents into the Lagoon (Fodeke, 1979). The level of mercury in fishes from Niger Delta area of Nigeria is less than $10 \mathrm{mg} / \mathrm{kg}$ (Kakulu and Osibanjo, 1986).In Nigeria, not much work has been done to investigate the relative bio-accumulation potential of mercury on local aquatic species (Oyewo, 1998). Some of the symptoms of mercury poisoning are irritability, excitability, restlessness, irrational outburst of temper, depression, headache and dizziness amongst others (Grant and Lipman, 2009). Other symptoms of mercury poisoning include itching, burning, pain, pink cheeks, swelling of fingertips and toes and shedding of the skin. A person suffering from mercury poisoning may experience profuse sweating, tachycardia, increased salivation, and hypertension (Lucky, 1987; Langford and Ferner, 1999). Affected children may show red cheeks, nose and lips, loss of hair, teeth, and nails, transient rashes, muscle weakness, kidney dysfunction, memory impairment and insomnia (Horowitz et al., 2002; Liuji et al., 2002). Ascorbic acid is a natural antioxidant that prevents the production of free radicals induced by oxidative damage to lipids and lipoproteins in various compartments of cells and tissues (Padayatty et al., 2003; WHO, 2003). Antioxides have been shown to react with superoxides (Nishikimi, 1975, WHO, 2004), hydroxyl radicals (McGregor and Biesalski, 2006) and singlet oxygen (Moreira et al., 2010). Ascorbic acid is an anti-oxidative substance that may protect the cells against the effects of free radicals which are molecules produced when the body breaks down foods or by exposure to tobacco smoke and radiation (Chihuailafet al., 2002). These anti-oxides are regarded as firstline protective agents that nullify free radicals by donating a single electron to yield dehydroascorbic acid (Valkoet al., 2005; Gemma et al., 2010). The aim of the present study was to evaluate the effect of ascorbic acid on mercuric chloride-induced changes on the cerebellar cortex of adult Wistar rats.

\section{MATERIALS AND METHODS}

\section{Experimental Animals}

Thirty adult Wistar rats of average weight of $200 \mathrm{~g}$ were used for this study and were acclimatized for three weeks and kept in the Animal house of the Department of Human Anatomy, Faculty of Medicine Ahmadu Bello University Zaria. The rats were then divided into six groups of five rats per Group for the experiment.

\section{Experimental Chemicals}

Twenty grams of mercuric chloride manufactured by May and Bakers Chemical Laboratory Limited Dagenham England while Vitamin C tablets manufactured by Jopan Pharmaceuticals Ltd. were purchased and used for the experiment.

\section{Animal Experimentation}

Twenty Wistar rats were divided into 6 Groups of 5 animals each. Group 1 (Control) was administered with distilled water, Group 2 was given $52.5 \mathrm{mg} / \mathrm{kg}$ body weight of mercuric chloride $(\mathrm{Hg})$, Group 3 animals were administered with $26.25 \mathrm{mg} / \mathrm{kg}$ body weight of $\mathrm{Hg}$, corresponding to $25 \%$ and $12.5 \%$ of $\mathrm{LD}_{50}$ of $\mathrm{Hg}$ respectively (Lucky, 1987). Animals in Group 4 were given $52.5 \mathrm{mg} / \mathrm{kg}$ body weight of $\mathrm{Hg}$ and $5 \mathrm{mg} / \mathrm{kg}$ body weight of ascorbic acid, while Group 5 animals were administered with $26.25 \mathrm{mg} / \mathrm{kg}$ body weight of $\mathrm{Hg}$ and $5 \mathrm{mg} / \mathrm{kg}$ body weight of ascorbic acid and Group 6 rats were administered with $5 \mathrm{mg} / \mathrm{kg}$ body weight of ascorbic acid only corresponding to $10 \%$ of $\mathrm{LD}_{50}$ of ascorbic acid (UKFSA, 2007). The administration was by oral route daily and lasted for 3 weeks while animal feed and drinking water was allowed ad libitum.

\section{Animals Sacrifice}

After the administration, the animals were weighed, humanely sacrificed and incision was made through the skin and muscle of the skull. The skull was opened through amid sagittal incision and the cerebellum was removed and fixed in Bouin's fluid. The tissues were routinely processed and stained using haematoxylin and eosin and crystal violet.

\section{Estimation of Oxidative Parameters Determination of Catalase Activity}

Catalase activity was determined using the method described by Sinha, (1972) and the 
absorbance was read at $570 \mathrm{~nm}$. Standard cure was made by plotting the absorbance obtained at various levels of the assay. The catalase activity was obtained from the graph of the standard curve.

\section{Determination of superoxide dismutase (SOD) activity}

Superoxide Dismutase (SOD) activity was determined by a method described by Fridovich, (1989). Absorbance was measured every 30 seconds up for a total of 150 seconds at $480 \mathrm{~nm}$ from where the SOD activity was calculated.

\section{Assessment of lipid peroxidation}

Lipid peroxidation as evidenced by the formation of TBARS was measured by the method of Niehaus and Samuelson (1968). The absorbance of the pink supernatant was measured against a reference blank using a spectrophotometer at $535 \mathrm{~nm}$.

\section{Assay of reduced Glutathione concentration}

Reduced glutathione (GSH) concentration measurements were done according to the method of Ellman (1959) as described by Rajagopalan et al. (2004), and the absorbance was read at $412 \mathrm{~nm}$.

\section{Statistical Analysis}

All data were presented as mean \pm SD. For establishing significant differences, data were analyzed by one-way analysis of variance (ANOVA), followed by Tukeypost hoc test. Values were considered statistically significant if $\mathrm{P}$ value was $\mathrm{p} \leq 0.05$.

\section{RESULTS}

\section{Physical Observation of the animals}

The result of physical observation of the animals showed that rats in Group 1 were very active while Group 2 animals showed less activity, gnawing and restlessness with watery feces. The animals in Group 3 showed gnawing and restlessness, characterized by watery feces while, Group 4 animals exhibited restlessness. The result of physical observation showed little gnawing in Group 5 animals with more activity when compared to Group 2 and Group 4 while Group 6 animals showed no changes in their physical activity as in Group one.

\section{Oxidative Parameters}

The result of the analysis of oxidative stress markers namely catalase, SOD, glutathione reductase and lipid peroxidation following administration of mercuric chloride and ascorbic acid showed increase and decrease in some parameters as shown in Table 1 . The result showed a significant decrease $(\mathrm{P}<0.05)$ in catalase, SOD and glutathione reductase in Groups 2, 3 and 4 when compared with the Control, and a significant increase $(\mathrm{P}<0.05)$ in lipid peroxidase in Groups 2 and 3, and a significant decrease $(\mathrm{P}<0.05)$ in Groups 5 and 6 when compared with the Control as shown in table 1.

Table1: Effect of ascorbic acid on mercuric chloride-induced changes on the oxidative markers in experimental animals

\begin{tabular}{|c|c|c|c|c|c|}
\hline S/N & Groups & $\begin{array}{l}\text { CATmm/ml } \\
\text { Mean } \pm \text { SD }\end{array}$ & $\begin{array}{l}\text { SOD }(\text { mUnits/L }) \\
\text { Mean } \pm \text { SD }\end{array}$ & $\begin{array}{l}\text { GLU }(\mathrm{mm} / \mathrm{ml}) \\
\text { Mean } \pm \text { SD }\end{array}$ & $\begin{array}{l}\mathrm{LPO}(\mu \mathrm{M} / \mathrm{L}) \\
\text { Mean } \pm \mathrm{SD}\end{array}$ \\
\hline 1 & $\begin{array}{c}\mathrm{I} \\
\text { (control) }\end{array}$ & $23.25 \pm 1.19$ & $604.65 \pm 60.32$ & $14.29 \pm 1.19$ & $57.46 \pm 3.35$ \\
\hline 2 & $\begin{array}{c}\text { II } \\
52.5 \mathrm{mg} \mathrm{HgCl}_{2}\end{array}$ & $12.52 \pm 5.30 *$ & $358.15 \pm 12.94 *$ & $10.04 \pm 1.16^{*}$ & $91.55 \pm 6.24 *$ \\
\hline 3 & $\begin{array}{c}\text { III } \\
26.25 \mathrm{mg} \mathrm{HgCl}\end{array}$ & $13.52 \pm 5.62 *$ & $382.75 \pm 24.39 *$ & $11.54 \pm 3.03 *$ & $70.39 \pm 6.59^{*}$ \\
\hline 4 & \begin{tabular}{l}
\multicolumn{1}{c}{ IV } \\
$52.5 \mathrm{mg} / \mathrm{kg}$ \\
$\mathrm{HgCl}_{2}+\mathrm{Vit} . \mathrm{C}$
\end{tabular} & $18.18 \pm 1.28^{*}$ & $472.75 \pm 77.15^{*}$ & $12.50 \pm 2.26^{*}$ & $52.82 \pm 14.79$ \\
\hline 5 & $\begin{array}{c}\mathrm{V} \\
26.25 \mathrm{mg} / \mathrm{kg} \\
\mathrm{HgCl}_{2}+\text { Vit. C }\end{array}$ & $20.29 \pm 3.57$ & $526.50 \pm 50.21$ & $13.57 \pm 0.81$ & $47.75 \pm 3.25^{*}$ \\
\hline 6 & $\begin{array}{c}\text { VI } \\
\text { Vit.C5mg/ kg } \\
\end{array}$ & $20.61 \pm 3.32$ & $580.25 \pm 35.71$ & $14.05 \pm 1.35$ & $41.86 \pm 5.78^{*}$ \\
\hline
\end{tabular}

*P $<0.05, \mathrm{CAT}=$ Catalase; $\mathrm{SOD}=$ Superoxide Dismutase; GLU=Glutathione Reductase; $\mathrm{LPO}=$ Lipid peroxidation 


\section{Histological Observation}

The histological observation of the cerebellar cortex of animals in Group 1, showed normal histomorphology of the cerebellar cortical cells and layers as shown in Figure 1 while the cerebellum of the animals in Group 2 showed degeneration and necrosis of the Purkinje cells of the Purkinje cell layer of the cerebellar cortex as shown in Figure 2. The cerebellum of animals in Group 3 showed separation of the Purkinje cells due to degeneration of Purkinje cells, degenerated Stallate cells in the cerebellum as shown in Figure 3 while the cerebellar cortices of animals in Group 4 showed few degeneration

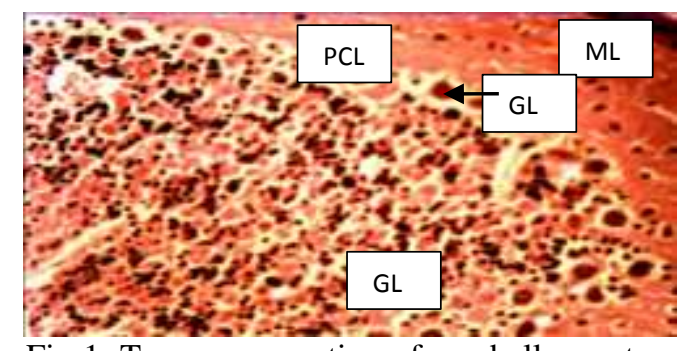

Fig 1. Transverse section of cerebellar cortex of the Control Group, showing normal Molecular layer (ML), Purkinje cell layer (PCL), Purkinje cells (PC) and Granular layer (GL). H\&E X250

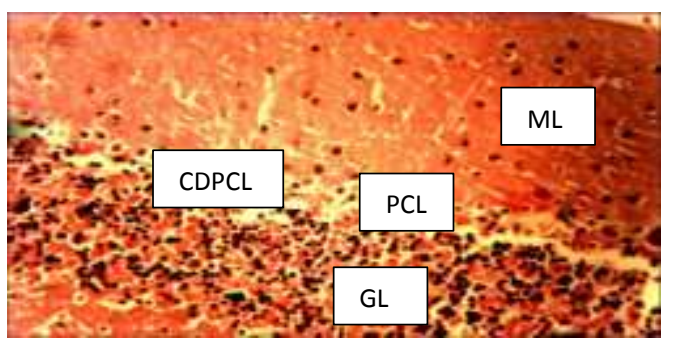

Fig 2. Transverse section of cerebellar cortex of animals in Group 2, showing the Molecular layer (ML), Purkinje cell layer (PCL), Complete degeneration of Purkinje cells (CDPC) with no Purkinje cell and Granular layer (GL). H \& E, Mg X 250

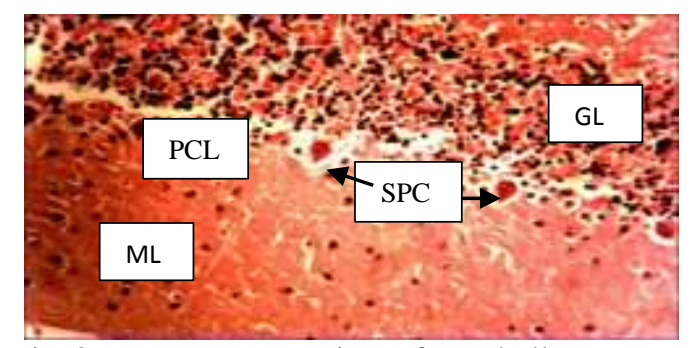

Fig 3: Transverse section of cerebellar cortex of animals in Group 3, showing the Molecular layer (ML), separated Purkinje cells (SPC) and Granular layer (GL). H\&E, X250 of Purkinje cells of the cerebellum with clumping and congestion of cells as shown in Figure 4. The cerebellar cortices of animals in Group 5 showed displacement of Purkinje cell nuclei, separation of Purkinje cells due to the degeneration of Purkinje cells and the granular and molecular layers of the cerebellum were not affected as shown in Figure 5, while the results of the observation of the cerebellar cortices of animals in Group 6showednormal arrangement of the layers and cells of the cerebellum as shown in Figure 6.

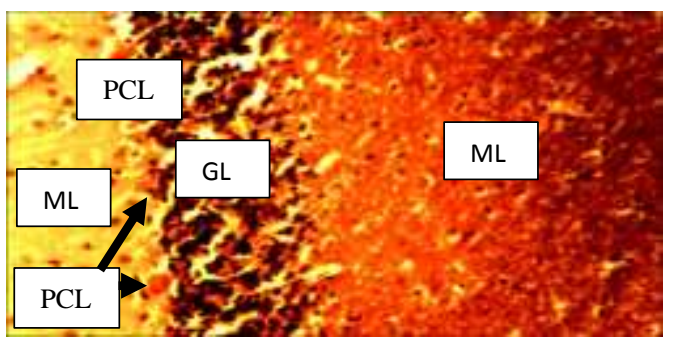

Fig 4. Transverse section of cerebellar cortex of animals in Group 4, showing the Molecular layer (ML), Degenerated Purkinje cells (DPC) and Granular layer (GL). H\&E, X 250

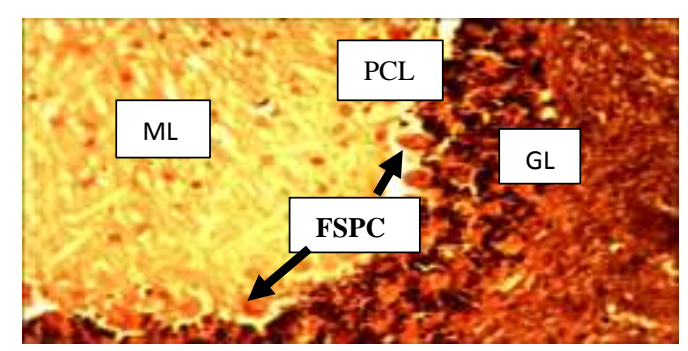

Fig 5: Transverse section of the cerebellar cortex of the animals in Group 5, showing the Molecular layer (ML), Purkinje Cell Layer (PCL) with few and separated Purkinje cells (FSPC) and Granular layer (GL). H\&E, X250

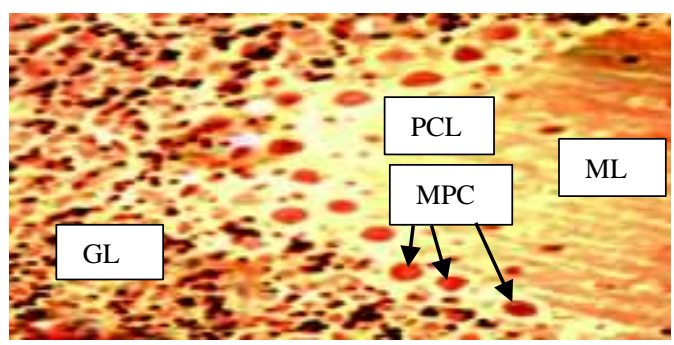

Fig 6: Transverse section of the cerebellar cortex of animals in Group 6, showing the Molecular layer (ML), Purkinje Cell Layer (PCL), with many Purkinje cells (MPC) and normal Granular layer (GL). H\&E, X250 


\section{DISCUSSION}

The present study showed degeneration and necrosis of Purkinje cells in the Purkinje cell layers of the cerebellum of adult Wistar rats induced with different concentration of mercuric chloride. All layers and cells of the cerebellum of the Control group showed no histological changes. The findings from the present study agree with the findings which reported that many heavy metals such as mercury, lead, cadmium and other organic compounds have the capacity to damage the nervous system (Maurice et al., 1972; Verina et al., 2007). These changes may be transient but permanent abnormalities may be induced only by sustained exposure of these chemicals in an excessive quantity (Wolf et al., 2009). Recent studies have shown that the most sensitive elements of the cerebellar cortex to these chemicals are the Purkinje cells, which react to these noxious substances by undergoing degeneration and as such disappear from their relative positions in the Purkinje cell layer (Jomova and Volko, 2011; Farina et al., 2013). It has been shown that cerebellar dysfunction may occur in association with exposure to a wide variety of toxins including heavy metals such as mercury, lead, thallium, manganese, drugs and solvents (Woodside et al., 2005; Burger et al., 2013). These toxins may adversely affect the cerebellum directly or as part of a more generalized brain effects (Jomova et al., 2011). Findings from other studies, show that the cerebellar neurodegeneration will lead to lesions of the cerebellum giving rise to signs and symptoms generally called cerebellar syndromes which include muscular hypotonia, intentional tremor, nystagmus, scanning speech and ataxic gait (Fine et al., 2002; Gemma et al., 2007; Wolf et al., 2009). The present study has shown that ascorbic acid has an ameliorative effect on the cerebellum of the experimental animals induced toxicity of the mercury chloride. Administration of ascorbic acid has shown some improvements in the prevention of degeneration of brain cells when compared with rats exposed to only mercuric chloride. From the present observation, it has been shown that there is a direct relationship between the concentration of mercuric chloride, ascorbic acid and the level of neurological damage in the cerebellum. The present study showed that the ascorbic acid administration reduced the damage done to the cerebellum was in agreement with the findings that showed that natural agents rich in antioxidants are involved in the improvement in enzymatic activity and hence in the reduction of oxidative stress (Ahamed and Siddiqui, 2007; Farina et al., 2013). This may play a significant role in the reversion of mercury toxicity by forming inert complexes and inhibiting their toxicity on the dopaminergic neurons (Flora et al., 2007; Jomovaand Volko, 2011). The present study showed a significant increase in the mean SOD levels in the experimental groups and a significant decrease in the LPO mean values when compared to the Control. Theincrease and decrease in the mean values of SOD and LPO could be related to the ameliorative effects of the antioxidative activities of ascorbic acid on mercury induced toxicity in the experimental animals. It has been shown that heavy metals such as mercury, lead and thallium reduce antioxidative enzymes such as SOD, CAT, GLU and Lipid peroxidase (LPO) (Woodside et al., 2005; Farina et al., 2013). The present study agrees with the findings that showed that oxidative stress was an important component of the mechanism of toxicity by heavy metals (Gutierrez et al., 2006). It has been shown that acute exposure to mercury increases LPO and decreases SOD levels in experimental animals. The decrease in the activity of antioxidative enzymes such as superoxide dismutase level and the elevation of Lipid peroxidation, suggest the formation of free radicals and the participation of free radical induced oxidative cell injury in mediating the toxic effect of mercury (Jomva et al., 2010). There is reduction in the antioxidant defense system by SOD in mercury toxicity leading to the disruption of pro-antioxidant balance in the body. The increase in Lipid peroxidation might be due to peroxidation of unsaturated fatty acids within the cells in the body. Thus, increased lipid peroxidation is suggestive of progressive increase in cellular deformity, increase in membrane permeability and rigidity, and disruption of structural and functional integrity of cell organelles (Gemma et al., 2007).

\section{CONCLUSION}

Mercury exposure has induced degeneration in the cerebellar features of the adult Wistar rats and ascorbic acid has shown to significantly protect the neurotoxicity induced by mercuric chloride administration. As such, people exposed to mercury poison should consume food rich in ascorbic acid along with other antioxidants. 


\section{REFERENCES}

Ahamed M and Siddiqui MK (2007). Low level lead exposure and oxidative stress: Current opinions. Clin Chim Acta; 383: 57-64.

ATSDR (1999). Toxicological profile for mercury. Agency for Toxic Substances and Disease Registry. US Department of Health and Human Services. Atlanta, US.

Brian G and Fred S (1995). Distribution and effect of mercury. Mercury action news,vol 3:3.

Burger J and Gochfeld M (2011). Mercury and selenium levels in 19 species of saltwater fish from New Jersey as a function of species, size, and season. Sci Total Environ. 15;409 (8) :141829.

Burger J, Jeitner C, Donio M, Pittfield T and Gochfeld M. (2013). Mercury and selenium levels, and selenium:mercury molar ratios of brain, muscle and other tissues in bluefish (Pomatomussaltatrix) from New Jersey, USA. Sci Total Environ. 15;443:278-86.

Burger J, Jeitner C and Gochfeld M (2011). Locational differences in mercury and selenium levels in 19 species of saltwater fish from New Jersey. J Toxicol Environ Health A. 74 (13): 863-74.

Chihuailaf RH, Contreras PA and Wittwer FG (2002). Pathogenesis of oxidative stress: Consequences and evaluation in animal health. Vet. Mex. 33(3): 265-283.

Clarkson TW (1989) Mercury. Journal of the American College of Toxicology. 84(7):12911296.

Cox R (1997). The Pillar of Celestial Fire.1st World Publishing p. 260.

De Bont B, Lauwerys $\mathrm{R}$, Govaerts $\mathrm{H}$ and Moulin D. (1986). Yellow mercuric oxide ointment and mercury intoxication. European Journal of Pediatrics, 145:217-218.

Ellman GL (1959) Tissue sulfhydryl groups. Arch. Biochem. Biophys.82, 70-72

European Commission. (2005). 101 Communication from the Commission to the Council and the European Parliament on Community Strategy Concerning Mercury
Extended Impact Assessment 101: 20 final 28, p. 12.

Farina M, Avila DS, da Rocha JB, Aschner M. (2013). Metals, oxidative stress and neurodegeneration: a focus on iron, manganese and mercury. Neurochem. Int. 62(5):575-594.

Fine EJ, Ionita CC and Lohr L (2002). The history of the development of the cerebellar examination. Semin. Neurol. 22 (4): 375-384.

Flora SJ, Saxena G and Mehta A (2007). Reversal of lead-induced neuronal apoptosis by chelation treatment in rats: Role of ROS and intracellular $\mathrm{Ca}^{+}$. Journal of Pharmacol Exp. Ther. 322:108-173.

Fodeke (1979): Studies on heavy metals and microbial contamination of Tilapia sp in Lagos Lagoon M.Sc Thesis University of Lagos.

Fridovich I (1989). Superoxide dismutase: An adaptation to a pragmatic gas. J. Biol. Chem. 264:7761-7764.

Gemma C, Bachstetter AD and Bickford PC. (2010). Neuron-Microglia dialogue and hippocampal neurogenesis in the aged brain. Aging Dis. 1(3):232-244.

Gemma C, Vila J, Bachstetter A and Bickford PC. (2007). Oxidative stress and the aging brain: From Theory to Prevention. In: Riddle DR, editor. Brain Aging: Models, Methods, and Mechanisms. Boca Raton (FL): CRC Press; Chapter 15.

Grant LD and Lipman M (2009). Environmental toxicant; Human exposure and their effect. $3^{\text {rd }} \mathrm{ed}$ 108-112.

Gutierrez LL, Mazzotti NG, Araujo, A, Klipel $\mathrm{R}$, Fernandes $\mathrm{T}$, Llesuy $\mathrm{F}$ and Bello-Klein A (2006). Peripheral markers of oxidative stress in chronic mercuric chloride intoxication. Journal of Medical and Biological Research.,39(6):767772 .

Horowitz Y, Greenberg D, Ling G, Lifshitz M (2002). Acrodynia: a case report of two. Arch Dis Child. 86 (6): 453. 
Jomova K and Valko M. (2011). Advances in metal-induced oxidative stress and human disease. Toxicology. 10;283(2-3):65-87.

Jomova K, Vondrakova D, Lawson M, Valko M. (2010). Metals, oxidative stress and neurodegenerative disorders. Mol. Cell Biochem. 345(1-2):91-104.

Kakulu SE and Osibanjo O. (1986). A baseline study of mercury in fish and sediments in the Niger Delta Area of Nigeria. Environmental Pollution (series B) II 315 - 322.

Langford N and Ferner R (1999). Toxicity of mercury. J Hum Hypertens. 13(10): 651-6

Liuji C, Xianqiang Y and Hongli J (2002). Teacatechins protect against lead induced cytotoxicity, lipid peroxidation, and membrane fluidity in HepG2 cells. Toxicol. Sciences, 69: 145-56.

Lucky TD (1987). Metal toxicity in mammals; New York plenum press. Pg: 20-28

Maurice V and James AF (1972). The nutritional and metabolic diseases of the cerebellum. Clinical and pathological aspects. In the cerebellum in health and diseases, edited by: William S. F. and William D. W. Adam Hilger, London. P. 412- 449.

McGregor GP and Biesalski HK (2006). Rationale and impact of vitamin $\mathrm{C}$ in clinical nutrition. Currtopin in clinnutr and metab care. 9(6): 697-703.

Moreira PI, Sayre LM, Zhu X, Nunomura A, Smith MA and Perry G (2010). Detection and localization of markers of oxidative stress by in situ methods: application in the study of Alzheimer disease. Methods Mol Biol. 610:41934.

Niehaus WG and Samuelson B (1968). Formation of malnaldehyde from phospholipid arachidonate during microsomal lipid peroxidation. Eur. Biochem; 6: 126-130.

Nishikimi M (1975). Oxidation of ascorbic acid with superoxide anion generated by the xanthine-xanthine oxidase system. Biochemistry and Biophysics Research Communication, 63: 463-468.
Oyewo EO. (1998): Industrial sources and distribution of heavy metals in Lagos lagoon and their biological effects on estuarine animals. $\mathrm{PhD}$ Thesis University of Lagos, Lagos.

Padayatty SJ, Katz A, Wang Y, Eck P, Kwon O, Lee J, Chen S and Corpe C. (2003). Vitamin C as an antioxidant: evaluation of its role in disease prevention. Journal of the American College of Nutrition, 22 (1): 18-35.

Rajagopalan H, Jallepalli PV, Rago C, Velculescu VE, Kinzler KW, Vogelstein B, Lengauer C. (2004). Inactivation of hCDC4 can cause chromosomal instability. Nature. 428(6978):77-81.

Sinha AK. (1972). Colorimetric assay of catalase. Anal. Biochem. 47, 389-399

UK Food Standards Agency. (2007).Vitamin C Risk Assessment. http://www.food.gov.uk/ multimedia/pdfs/evm_c.pdf

Valko M, Morris H and Cronin MT. (2005). Metals, toxicity and oxidative stress. Curr Med Chem. 12(10):1161-208.

Verina T, Rohde CA and Giularte TR (2007). Environmental lead exposure during early life alters granule cell neurogenesis and morphology in the hippocampus of young adult rats. Neuroscience, 145:1037-1047.

Wolf U, Rapoport MJ and Schweizer TA (2009). Evaluating the affective component of the cerebellar cognitive affective syndrome. Journal of Neuropsychiatry Clinical. Neurosciences, 21 (3): 245-53.

Woodside $\mathrm{J}$, McCall D, McGartland $\mathrm{C}$ and Young I (2005). Micronutrients: dietary intake vitamin C supplement use. Proc. Nutr. Soc. 64 (4): 543-53.

World Health Organization (WHO) (2003). Elemental mercury and inorganic mercury compounds: Human health aspects. Concise International Chemical Assessment Document. CICAD 50. Geneva.

World Health Organization (WHO) (2004). Vitamin and mineral requirements in human nutrition, $2^{\text {nd }}$ edition 